\title{
EFFECT OF PULSING IN PRESERVATIVE SOLUTIONS, GROWTH REGULATOR BA AND COLD STORAGE ON THE LONGEVITY OF CHRYSANTHEMUM CUT FLOWERS CV. ROYAL ACCENT
}

\author{
Nermeen M. Badawy'; Sohaier E. Hassan²; H.A.S. EI-Shoura²; M.H.M. \\ El-Shreif ${ }^{3}$ and Fatma El-Napwya M. El-Quesni ${ }^{1}$ \\ 1- Biological and Agricultural Research Division, Department of Ornamental Plants and Woody \\ Trees, National Research Center, Dokki, Giza, Egypt \\ 2- Department of Horticulture, Faculty of Agriculture, Ain Shams University, Cairo, Egypt \\ 3- Department of Botany, Faculty of Agriculture, Ain Shams University, Cairo, Egypt \\ *Corresponding author, email: aleman kair@yahoo.com
}

Keywords: Dendranthema morifolium, Pulsing, Preservative solutions, Growth regulators, Cold storage, Longevity, Chrysanthemum, Cut flowers

\section{ABSTRACT}

The interaction of pulsing in preservatives, growth regulators and cold storage on vase life and quality of Chrysanthemum (Dendranthema grandiflora) cut flowers was investigated. Chrysanthemum cut flowers were treated with benzyl adenine $(\mathrm{BA})$, silver nitrate $\left(\mathrm{AgNO}_{3}\right)$, cobalt sulfate $\left(\mathrm{CoSO}_{4}\right)$ and sodium hypochlorite $(\mathrm{NaOCl})$ and then were placed in cold storage at $5^{\circ} \mathrm{C}$ for periods of 1,2 and 3 weeks. Vase life, fresh weight, total chlorophyll and total carbohydrate were determined. Cold storage for one week and pulsing with $\mathrm{BA}$ and $\mathrm{AgNO}_{3}$ showed longest vase life, the lowest chlorophyll decrease and highest total carbohydrate content.

\section{INTRODUCTION}

Chrysanthemum (Dendranthema grandiflorum), family Asteraceae, is one of the most important cut flowers in the world. Addition of floral preservatives and also cold storage can extend vase life and improve flower quality in addition to cold storage for D. grandiflora var. Royal Accent (Carlson and Dole 2013).

Different chemicals with different roles were used, silver nitrate $\left(\mathrm{AgNO}_{3}\right)$ considered as an in- hibitor on growth of fungus and bacteria in the vase solution (Gupta et al 2006). Cobalt sulfate $\left(\mathrm{CoSO}_{4}\right)$ is used to encourage absorption of solution by flowers and cobalt works to increase the production of amino acid methionine a starter for a series of protein (Nabigol et al 2006). Sodium hypochlorite $(\mathrm{NaOCl})$ is considered as a microbial pesticide (Belle et al 2004). Eight - hydroxy quinoline sulfate (8 - HQS) is considered as a germicide (Witte et al 2014). Benzyl adenine (BA) is used to reduce the sensitivity of the flower for leaf yellowing, and relieves wilt and delays foliar chlorosis during storage and transport, and also has activity as an antioxidant enzyme such as catalase (Shimizu-Yumoto and Ichimura 2013). Citric acid (C.A.) is known also as an organic acid and a decreases $\mathrm{pH}$ solution (Macnish et al 2008). Sucrose also has the preservation of cell respiration, very important as a source of energy for the performance of biological processes inside the flower and has an organizer role for osmotic adjustment in vase solution (Doi and Reid 1995).

The obtained results were as follows: BA or $\mathrm{AgNO}_{3}+$ C. A. + sucrose $3 \%$ with cold storage for one week increased vase life, fresh weight, total chlorophylls and total carbohydrates of $D$. grandiflora cut flowers (Devecchi et al 2009 and RabizaSwider et al 2012). The best treatment gave the longest life flower, less decrease in the fresh weight and the largest fresh weight and the highest content of total chlorophyll and total carbohydrates in the leaves are citric acid $75 \mathrm{ppm}+$ sucrose $3 \%$ 
+ benzyl adenine $0.5 \mathrm{ml} \mathrm{mol}$ and the treatment of citric acid 75 ppm + sucrose $3 \%$ + silver nitrate 25 ppm with cold storage in the refrigerator for only one week compared with the other treatments.

\section{MATERIALS AND METHODS}

This study was carried out in the Lab. of Hort. Dept., Fac. of Agric., Ain Shams Univ., Cairo, Egypt, for the two successive seasons of 2012 and 2013 to investigate the effect of pulsing in preservative solutions, growth regulators and cold storage periods on the vase life, fresh weight, changes in total chlorophyll and total carbohydrate contents of Dendranthema grandiflora cv. Royal Accent cut flowers (purple ray petals).

Cut Chrysanthemum flowers were obtained from a private farm on $28^{\text {th }}$ of March 2012 and 2013. The flowers were cut at the commercial maturity and half opening of the petals when they began to open. Lower leaves were removed up to about $15 \mathrm{~cm}$ from the cut stem base. The flowers were then cut to $50 \mathrm{~cm}$ long and placed in vases containing a recently prepared $\left(1000 \mathrm{~cm}^{3}\right)$ of the following solutions before cold storage:

1- Citric acid at $75 \mathrm{ppm}+$ sucrose at $3 \%+$ benzyl adenine at $0.5 \mathrm{~mm}$.

2- Citric acid at $75 \mathrm{ppm}+$ sucrose at $3 \%+$ silver nitrate at $25 \mathrm{ppm}$.

3- Citric acid at $75 \mathrm{ppm}+$ sucrose at $3 \%+$ cobalt sulphate at $50 \mathrm{ppm}$.

4- Citric acid at $75 \mathrm{ppm}+$ sucrose at $3 \%$ + sodium hypochlorite at $50 \mathrm{ppm}$.

5- Control (distilled water).

The cut flowers were placed in these treatments for $24 \mathrm{~h}$ except for BA for $20 \mathrm{~min}$ as they were placed for 20 minute only and wrapped in wax paper then placed inside cartoon boxes and put were in the refrigerator at $5^{\circ} \mathrm{C}$ for 1,2 and 3 weeks and after exited from the refrigerator were dipped in one solution consisted of 8 - hydroxyquinoline sulfate at $300 \mathrm{ppm}+$ citric acid at $50 \mathrm{ppm}+$ sucrose at $2 \%$, for all treatments.

The following data were recorded (on flowers after the cold storage periods):

- Vase life (days): vase life was terminated when the edges of the petals curled, wilted and yellowing of the lower green leaves.

- Minimum decreasing of fresh weight (FW) of flower (as \%).

- Maximum increasing of FW of flowers (as \%).

- Total chlorophylls reading in leaves (SPAD) after 7 and 10 days of the beginning of experiment and before and after the different cold storage periods.

- Total carbohydrates in the leaves $(\mathrm{mg} / \mathrm{g}$ dry weight) before and after the different cold storage periods (Dubois et al 1956 and A.O.A.C. 2005).

The experiments were performed in the a laboratory as its temperature averaged $21 \pm 2{ }^{\circ} \mathrm{C}$, and relative humidity $50-60 \%$ and under light intensity of 1000 lux from cool white fluorescent lamps for $12 \mathrm{~h}$ during the day.

Total chlorophylls assay were measured by using a Chlorophyll Meter Minolta device SPAD 502 (Wood et al 1992). The results of total chlorophylls were expressed as SPAD. It measures the relative amount of total chlorophyll present by measuring the transmittance of the leaf in two wave bands $600-700$ and $400-500 \mathrm{~nm}$ and the youngest fully expanded mature leaves were used. The design of the experiment was a factorial in randomized complete blocks in 5 treatments of solutions and 3 cold storage periods with 3 replicates and every replicate had 3 flowers as periods of storage occupied the main plot and preservative occupied the sub plot. The differences between treatments were determined by using L.S.D. test according to (Snedecor and Cochran 1989). Data of vase life, increase of fresh weight and decrease of fresh weight were statistically analyzed using SAS procedures (SAS Institute Inc. 1996).

\section{RESULTS AND DISCUSSION}

\section{1- Minimum decrease of FW of flower (as \%)}

Data presented in Table (1) show that the minimum decrease of FW was noticed from treatments C. A. $75 \mathrm{ppm}+$ sucrose $3 \%+\mathrm{CoSO}_{4} 50 \mathrm{ppm}$ and C. A. $75 \mathrm{ppm}+$ sucrose $3 \%+\mathrm{NaOCl} 50 \mathrm{ppm}$ by values of $12.1 \%$ and $10.8 \%$, while the maximum decrease of FW was obtained from treatment C. A. $75 \mathrm{ppm}+$ sucrose $3 \%+\mathrm{AgNO}_{3} 25 \mathrm{ppm}$ by values of 14.7 and $15.8 \%$ and the differences between them were significant. Also, the minimum decrease of FW was found with one week storage $8.7 \%$ and $9 \%$, while the maximum was recorded with 3 weeks storage by values of 16.5 and $15.9 \%$ and the differences were significant. The minimum decrease of $\mathrm{FW}$ occurred with treatment C. A. 75 ppm + sucrose $3 \%+\mathrm{CoSO}_{4} 50 \mathrm{ppm}$ and 1 week storage which gave 6.9 and $7.5 \%$, but the maximum decrease of $\mathrm{FW}$ was reported with treatment C. A. $75 \mathrm{ppm}+$ sucrose $3 \%+$ BA $0.5 \mathrm{ml} \mathrm{mol}$ and 
Table 1. Effect of pulsing in preservative solutions, growth regulator and cold storage periods on minimum decreasing of fresh weight percentage (\%) of chrysanthemum cv. Royal Accent during the two seasons of 2012 and 2013

\begin{tabular}{|c|c|c|c|c|}
\hline \multirow{2}{*}{ Treatments } & \multicolumn{4}{|c|}{ First season } \\
\hline & 1 Week & 2 Weeks & 3 Weeks & Mean \\
\hline 1- C. A. $75 \mathrm{ppm}+$ sucrose $3 \%+$ BA $0.5 \mathrm{ml} \mathrm{mol}$ & $9.1 \mathrm{FG}$ & 12.3 DE & $17.7 \mathrm{~A}$ & $13 \mathrm{~B}$ \\
\hline 2- C. A. 75 ppm + sucrose $3 \%+\mathrm{AgNO}_{3} 25 \mathrm{ppm}$ & $9.3 \mathrm{FG}$ & $17.4 \mathrm{AB}$ & $17.5 \mathrm{AB}$ & $14.7 \mathrm{~A}$ \\
\hline 3- C. A. $75 \mathrm{ppm}+$ sucrose $3 \%+\mathrm{CoSO}_{4} 50 \mathrm{ppm}$ & $6.9 \mathrm{G}$ & $13.2 \mathrm{CD}$ & 16.1 AB & $12.1 \mathrm{~B}$ \\
\hline 4- C. A. $75 \mathrm{ppm}+$ sucrose $3 \%+\mathrm{NaOCl} 50 \mathrm{ppm}$ & 8.1 FG & $13.2 \mathrm{CD}$ & $15.7 \mathrm{ABC}$ & $12.3 \mathrm{~B}$ \\
\hline 5- Distilled water (control) & 10.1 EF & $14.8 \mathrm{BCD}$ & 15.3 $\mathrm{ABC}$ & $13.4 \mathrm{AB}$ \\
\hline Mean & $8.7 \mathrm{C}$ & $14.2 \mathrm{~B}$ & $16.5 \mathrm{~A}$ & \\
\hline \multirow{2}{*}{ Treatments } & \multicolumn{4}{|c|}{ Second season } \\
\hline & 1 Week & 2 Weeks & 3 Weeks & Mean \\
\hline 1- C. A. $75 \mathrm{ppm}+$ sucrose $3 \%+$ BA $0.5 \mathrm{ml} \mathrm{mol}$ & 9.4 FGH & 11.5 DEF & $17.2 \mathrm{~B}$ & $12.7 \mathrm{~B}$ \\
\hline 2- C. A. 75 ppm + sucrose $3 \%+\mathrm{AgNO}_{3} 25 \mathrm{ppm}$ & 9 FGH & $17.3 \mathrm{~B}$ & $21.1 \mathrm{~A}$ & $15.8 \mathrm{~A}$ \\
\hline 3- C. A. $75 \mathrm{ppm}+$ sucrose $3 \%+\mathrm{CoSO}_{4} 50 \mathrm{ppm}$ & $7.5 \mathrm{H}$ & 13.2 CDE & $14.8 \mathrm{BC}$ & $11.8 \mathrm{BC}$ \\
\hline 4- C. A. 75 ppm + sucrose $3 \%+\mathrm{NaOCl} 50$ ppm & $8.5 \mathrm{GH}$ & 11.2 DEFG & 12.7 CDE & $10.8 \mathrm{C}$ \\
\hline 5- Distilled water (control) & 10.4 EFG & 12.3 CDE & $13.4 \mathrm{CD}$ & $12.1 \mathrm{BC}$ \\
\hline Mean & $9 \mathrm{C}$ & $13.1 \mathrm{~B}$ & $15.9 \mathrm{~A}$ & \\
\hline
\end{tabular}

${ }^{*}$ C. A.: citric acid.

** Means with the same letter are not significantly different at $\mathrm{P}<0.05$ level according to Duncan's Multiple Range Test.

storage for 3 weeks and treatment C. A. 75 ppm + sucrose $3 \%+\mathrm{AgNO}_{3} 25 \mathrm{ppm}$ with storage for 3 weeks gave 17.7 and $21.1 \%$ and the differences were significant. These results were in agreement with (Meeteren et al 2000), who found that deionized water gave a sharp decrease after 1 - 3 days on chrysanthemum cv. Cassa cut flowers. However, (Talukdar et al 2004b), found that there is a positive effect of the holding solution on vase life of cut Chrysanthemum (Dendranthema grandiflorum Tzvelev) flowers, whereas the fresh weight loss during senescence was lowest by $33.65 \%$. Concerning postharvest quality, (Talukdar et al 2004a), in his work on Chrysanthemum (Dendranthema grandiflora Tzvelve) cut flowers found that the minimum loss in fresh weight occurred with distilled water.

\section{2- Maximum increase of FW of flowers (as \%)}

Data presented in Table (2) show that the maximum FW occurred with treatment C. A. 75 ppm + sucrose $3 \%+\mathrm{AgNO}_{3} 25 \mathrm{ppm}$ which gave 29.2 and $25.4 \%$, while the minimum FW was reported with treatment distilled water (control) which gave $17.4 \& 19.3 \%$ and the differences were significant.
The maximum fresh weight was obtained from cold storage for one week by value of 31.5 \& $30.8 \%$, but the minimum FW recorded with cold storage for three weeks was valued at $17.6 \& 15.5 \%$ and the differences were significant. The maximum FW showed in treatment C. A. $75 \mathrm{ppm}+$ sucrose $3 \%+$ $\mathrm{AgNO}_{3} 25 \mathrm{ppm}$ with 1 week of cold storage and treatment C. A. $75 \mathrm{ppm}+$ sucrose $3 \%+$ BA $0.5 \mathrm{ml}$ mol with one week cold storage valued at 35.5 and $35.2 \%$, also the minimum FW was noticed with treatment distilled water (control) with 3 weeks of cold storage was estimated at 13.1 \& $14.3 \%$ and the differences were significant. The data were in agreement with (Meeteren et al 2000) who found that deionized water as vase water and a control solution treatment enhanced fresh weight probably by reducing bacterial growth in the cut open vessels. Also, (Ichimura et al 1999) stated that in cut Roses (Rosa hybrida cv. Sonia) flowers treated with sucrose + HQS was the most effective treatment in fresh weight that markedly increased it $20^{\circ} \mathrm{C}$. In addition, (Elanchezhian and Srivastava 2001) in their work on chrysanthemum found that the fresh weight was greatest in flowers kept in GA or control solution. 
Table 2. Effect of pulsing with preservative solutions, growth regulators and cold storage periods on maximum increase of fresh weight percentage (\%) of chrysanthemum cv. Royal Accent during the two seasons of 2012 and 2013

\begin{tabular}{|c|c|c|c|c|}
\hline \multirow{2}{*}{ Treatments } & \multicolumn{4}{|c|}{ First season } \\
\hline & 1 Week & 2 Weeks & 3 Weeks & Mean \\
\hline 1- C. A. $75 \mathrm{ppm}+$ sucrose $3 \%+$ BA $0.5 \mathrm{ml} \mathrm{mol}$ & $35.2 \mathrm{~A}$ & $25.9 \mathrm{BCD}$ & 18.1 DEF & $26.4 \mathrm{AB}$ \\
\hline 2- C. A. $75 \mathrm{ppm}+$ sucrose $3 \%+\mathrm{AgNO}_{3} 25 \mathrm{ppm}$ & $35.5 \mathrm{~A}$ & $32.6 \mathrm{AB}$ & 19.5 CDEF & $29.2 \mathrm{~A}$ \\
\hline 3- C. A. 75 ppm + sucrose $3 \%+\mathrm{CoSO}_{4} 50$ ppm & $33.1 \mathrm{AB}$ & $27.2 \mathrm{BC}$ & 18.5 DEF & $26.3 \mathrm{AB}$ \\
\hline 4- C. A. 75 ppm + sucrose $3 \%+\mathrm{NaOCl} 50$ ppm & $31.9 \mathrm{AB}$ & 20.2 CDEF & 18.5 DEF & $23.5 \mathrm{~B}$ \\
\hline 5- Distilled water (control) & $21.9 \mathrm{CDE}$ & 17.1 EF & $13.1 \mathrm{~F}$ & $17.4 \mathrm{C}$ \\
\hline Mean & $31.5 \mathrm{~A}$ & $24.6 \mathrm{~B}$ & $17.6 \mathrm{C}$ & \\
\hline \multirow{2}{*}{ Treatments } & \multicolumn{4}{|c|}{ Second season } \\
\hline & 1 Week & 2 Weeks & 3 Weeks & Mean \\
\hline 1- C. A. $75 \mathrm{ppm}+$ sucrose $3 \%+$ BA $0.5 \mathrm{ml} \mathrm{mol}$ & $35.2 \mathrm{~A}$ & $21 \mathrm{CDEFG}$ & $14.9 \mathrm{G}$ & 23.7 AB \\
\hline 2- C. A. $75 \mathrm{ppm}+$ sucrose $3 \%+\mathrm{AgNO}_{3} 25 \mathrm{ppm}$ & $34 \mathrm{~A}$ & 26.2 ABCDE & 15.9 FG & $25.4 \mathrm{~A}$ \\
\hline 3- C. A. $75 \mathrm{ppm}+$ sucrose $3 \%+\mathrm{CoSO}_{4} 50 \mathrm{ppm}$ & $32.3 \mathrm{AB}$ & 21.5 CDEFG & $15.2 \mathrm{G}$ & $23 \mathrm{AB}$ \\
\hline 4- C. A. 75 ppm + sucrose $3 \%+\mathrm{NaOCl} 50 \mathrm{ppm}$ & 27.8 ABCD & $30.1 \mathrm{ABC}$ & 17.4 EFG & $25.1 \mathrm{~A}$ \\
\hline 5- Distilled water (control) & 24.5 BCDEF & 19.1 DEFG & $14.3 \mathrm{G}$ & $19.3 \mathrm{~B}$ \\
\hline Mean & $30.8 \mathrm{~A}$ & $23.6 \mathrm{~B}$ & $15.5 \mathrm{C}$ & \\
\hline
\end{tabular}

${ }^{*}$ C. A.: citric acid.

** Means with the same letter are not significantly different at $\mathrm{P}<0.05$ level according to Duncan's Multiple Range Test.

\section{3- Vase life}

Data presented in Table (3) indicate that the longest vase life was determined with treatments C. A. $75 \mathrm{ppm}+$ sucrose $3 \%+$ BA $0.5 \mathrm{ml} \mathrm{mol} \&$ C. A. $75 \mathrm{ppm}+$ sucrose $3 \%+\mathrm{AgNO}_{3} 25 \mathrm{ppm}$ with values of $8.7 \& 8.7$ days and treatment C. A. 75 ppm + sucrose $3 \%+$ BA $0.5 \mathrm{ml} \mathrm{mol}$ with value of 7.9 days, also the shortest vase life was noticed was with treatment distilled water (control) with values of $6.3 \& 5.2$ days and the differences were significant. In addition, the longest vase life was found with cold storage period for 1 week was valued at 10.5 and 9.3 days, meanwhile the shortest vase life occurred with cold storage period for 3 weeks 3.3 \& 3.2 days and the differences in between them were significant. The longest vase life was obtained was with treatments C. A. $75 \mathrm{ppm}+$ sucrose $3 \%+\mathrm{AgNO}_{3} 25 \mathrm{ppm} \&$ C. A. $75 \mathrm{ppm}+$ sucrose $3 \%+$ BA $0.5 \mathrm{ml} \mathrm{mol}$ and one week of cold storage period as valued by 11.7 \& 10.3 days, while, the shortest vase life occurred with treatment distilled water (control) and 3 weeks of cold storage period which gave $2.2 \& 1.8$ days and the differences were significant. These data are in agreement with Shimizu-Yumoto and Ichimura (2013) who found that spraying or pulsing Dahlia cut flowers with (BA) 6 - benzylaminopurine treatments significantly extended the vase life of florets more than those treated with distilled water. Also, Macnish et al (2010) found that Iris cut flowers when treated with $20 \%$ sucrose plus $\mathrm{GA}_{3}$ had an additive effect on increasing the vase life by a further $0.8 \mathrm{~d}$ up to 1.5 day and pulsing stems with combined treatment prior to storing flowers dry for 14 day at $0^{\circ} \mathrm{C}$ provided maximum display life after storage.

\section{4- Percentage of total chlorophyll decrease (\%)}

Data presented in Table (4) show that the lowest decrease of chlorophyll content occurred from treatment C. A. $75 \mathrm{ppm}+$ sucrose $3 \%+$ BA $0.5 \mathrm{ml}$ mol with 1 week storage period by 20 and $18 \%$, while the highest decrease of chlorophyll content was obtained from treatment distilled water (control) with 3 weeks storage period by 50 \& $45 \%$. The data were in agreement with (Pandya and Saxena 2003) who found an increase in the total 
Table 3. Effect of pulsing with preservative solutions, growth regulators and cold storage periods on vase life (days) of chrysanthemum cv. Royal Accent during the two seasons of 2012 and 2013

\begin{tabular}{|c|c|c|c|c|}
\hline \multirow{2}{*}{ Treatments } & \multicolumn{4}{|c|}{ First season } \\
\hline & 1 Week & 2 Weeks & 3 Weeks & Mean \\
\hline 1- C. A. 75 ppm + sucrose $3 \%+$ BA $0.5 \mathrm{ml} \mathrm{mol}$ & $11.5 \mathrm{~A}$ & 10.6 AB & $3.8 \mathrm{E}$ & $8.7 \mathrm{~A}$ \\
\hline 2- C. A. $75 \mathrm{ppm}+$ sucrose $3 \%+\mathrm{AgNO}_{3} 25 \mathrm{ppm}$ & $11.7 \mathrm{~A}$ & 10.6 AB & $3.9 \mathrm{E}$ & $8.7 \mathrm{~A}$ \\
\hline 3- C. A. 75 ppm + sucrose $3 \%+\mathrm{CoSO}_{4} 50 \mathrm{ppm}$ & $10.6 \mathrm{AB}$ & $10.5 \mathrm{AB}$ & $3.5 \mathrm{E}$ & $8.2 \mathrm{~A}$ \\
\hline 4- C. A. 75 ppm + sucrose $3 \%+\mathrm{NaOCl} 50$ ppm & $10 \mathrm{BC}$ & $9.2 \mathrm{C}$ & 3.2 EF & $7.5 \mathrm{~B}$ \\
\hline 5- Distilled water (control) & 8.8 CD & $7.8 \mathrm{D}$ & $2.2 \mathrm{~F}$ & $6.3 \mathrm{C}$ \\
\hline Mean & $10.5 \mathrm{~A}$ & $9.8 \mathrm{~B}$ & $3.3 \mathrm{C}$ & \\
\hline \multirow{2}{*}{ Treatments } & \multicolumn{4}{|c|}{ Second season } \\
\hline & 1 Week & 2 Weeks & 3 Weeks & Mean \\
\hline 1- C. A. $75 \mathrm{ppm}+$ sucrose $3 \%+$ BA $0.5 \mathrm{ml} \mathrm{mol}$ & $10.3 \mathrm{~A}$ & $8.9 \mathrm{AB}$ & $4.5 \mathrm{CD}$ & $7.9 \mathrm{~A}$ \\
\hline 2- C. A. $75 \mathrm{ppm}+$ sucrose $3 \%+\mathrm{AgNO}_{3} 25 \mathrm{ppm}$ & $10.2 \mathrm{~A}$ & $8.5 \mathrm{~B}$ & 3.8 DE & $7.5 \mathrm{AB}$ \\
\hline 3- C. A. $75 \mathrm{ppm}+$ sucrose $3 \%+\mathrm{CoSO}_{4} 50 \mathrm{ppm}$ & $9.2 \mathrm{AB}$ & $8.2 \mathrm{~B}$ & 3.2 DEF & $6.9 \mathrm{BC}$ \\
\hline 4- C. A. 75 ppm + sucrose $3 \%+\mathrm{NaOCI} 50$ ppm & $8.9 \mathrm{AB}$ & $7.8 \mathrm{~B}$ & 2.8 EF & $6.5 \mathrm{C}$ \\
\hline 5- Distilled water (control) & $7.8 \mathrm{~B}$ & $5.9 \mathrm{C}$ & $1.8 \mathrm{~F}$ & $5.2 \mathrm{D}$ \\
\hline Mean & $9.3 \mathrm{~A}$ & $7.9 \mathrm{~B}$ & $3.2 \mathrm{C}$ & \\
\hline
\end{tabular}

${ }^{*}$ C. A.: citric acid.

** Means with the same letter are not significantly different at $\mathrm{P}<0.05$ level according to Duncan's Multiple Range Test.

Table 4. Effect of pulsing with preservative solutions, growth regulators and cold storage periods on mean of decreasing rate of total chlorophyll (\%) in the leaves of chrysanthemum cv. Royal Accent during the two seasons of 2012 and 2013

\begin{tabular}{|c|c|c|c|}
\hline \multirow{2}{*}{ Treatments } & \multicolumn{3}{|c|}{ First season } \\
\hline & 1 Week & 2 Weeks & 3 Weeks \\
\hline 1- C. A. $75 \mathrm{ppm}+$ sucrose $3 \%+$ BA $0.5 \mathrm{ml} \mathrm{mol}$ & 20 & 23 & 25 \\
\hline 2- C. A. $75 \mathrm{ppm}+$ sucrose $3 \%+\mathrm{AgNO}_{3} 25 \mathrm{ppm}$ & 22 & 28 & 35 \\
\hline 3- C. A. $75 \mathrm{ppm}+$ sucrose $3 \%+\mathrm{CoSO}_{4} 50 \mathrm{ppm}$ & 22 & 26 & 29 \\
\hline 4- C. A. 75 ppm + sucrose $3 \%+\mathrm{NaOCl} 50$ ppm & 25 & 29 & 30 \\
\hline 5- Distilled water (control) & 35 & 45 & 50 \\
\hline \multirow{2}{*}{ Treatments } & \multicolumn{3}{|c|}{ Second season } \\
\hline & 1 Week & 2 Weeks & 3 Weeks \\
\hline 1- C. A. 75 ppm + sucrose $3 \%+$ BA $0.5 \mathrm{ml} \mathrm{mol}$ & 18 & 22 & 27 \\
\hline 2- C. A. $75 \mathrm{ppm}+$ sucrose $3 \%+\mathrm{AgNO}_{3} 25 \mathrm{ppm}$ & 21 & 25 & 32 \\
\hline 3- C. A. 75 ppm + sucrose $3 \%+\mathrm{CoSO}_{4} 50$ ppm & 20 & 26 & 30 \\
\hline 4- C. A. 75 ppm + sucrose $3 \%+\mathrm{NaOCl} 50$ ppm & 23 & 28 & 35 \\
\hline 5- Distilled water (control) & 32 & 38 & 45 \\
\hline
\end{tabular}


chlorophyll content of leaves in cut flowers of Dendranthema grandiflora when treated with $6 \%$ sucrose solutions as improved the quality and vase life. Notably, (Mutui et al 2001) found that A/stroemeria aurantiaca cut flowering stems held in $25 \mathrm{mg} /$ litre BA as a commercial preservative, significantly increased the chlorophyll content.

\section{5- Total carbohydrates (\%)}

Data presented in Table (5) show that the highest total carbohydrates (\%) was recorded from treatment C. A. $75 \mathrm{ppm}+$ sucrose $3 \%+\mathrm{NaOCl} 50$ ppm with one week cold storage period which gave $31.2 \& 46.2 \%$, whereas the lowest total carbohydrates content was found with treatment distilled water (control) and three weeks cold storage period which gave 1.9 \& $6.2 \%$. The data are in agreement with (Pandya and Saxena 2003) who found that there was a correlation between carbohydrates content and vase life of Chrysanthemum morifolium cut flowers. Also, (Ichimura et al 1999) on cut Roses (Rosa hybrida cv. Sonia) flowers found that soluble carbohydrates concentration in petals is an important factor in determining the vase life.

Table 5. Effect of pulsing with preservative solutions, growth regulators and cold storage periods on mean of total carbohydrates (\%) in chrysanthemum cv. Royal Accent during the two seasons of 2012 and 2013

\begin{tabular}{|c|c|c|c|}
\hline \multirow{2}{*}{ Treatments } & \multicolumn{3}{|c|}{ First season } \\
\hline & 1 Week & 2 Weeks & 3 Weeks \\
\hline \multirow{5}{*}{$\begin{array}{l}\text { 1- C. A. } 75 \mathrm{ppm}+\text { sucrose } 3 \%+\mathrm{BA} 0.5 \mathrm{ml} \mathrm{mol} \\
\text { 2- C. A. } 75 \mathrm{ppm}+\text { sucrose } 3 \%+\mathrm{AgNO}_{3} 25 \mathrm{ppm} \\
\text { 3- C. A. } 75 \mathrm{ppm}+\text { sucrose } 3 \%+\mathrm{CoSO}_{4} 50 \mathrm{ppm} \\
\text { 4- C. A. } 75 \mathrm{ppm}+\text { sucrose } 3 \%+\mathrm{NaOCl}_{50 \mathrm{ppm}} \\
\text { 5- Distilled water (control) }\end{array}$} & 20.2 & 17.2 & 13.2 \\
\hline & 20.2 & 13.2 & 6.2 \\
\hline & 25.2 & 20.2 & 12.5 \\
\hline & 31.2 & 24.2 & 13.2 \\
\hline & 13.5 & 6.2 & 1.9 \\
\hline \multirow{2}{*}{ Treatments } & \multicolumn{3}{|c|}{ Second season } \\
\hline & 1 Week & 2 Weeks & 3 Weeks \\
\hline 1- C. A. $75 \mathrm{ppm}+$ sucrose $3 \%+$ BA $0.5 \mathrm{ml} \mathrm{mol}$ & 34.2 & 16.5 & 8.2 \\
\hline 2- C. A. $75 \mathrm{ppm}+$ sucrose $3 \%+\mathrm{AgNO}_{3} 25 \mathrm{ppm}$ & 27.2 & 16.2 & 7.5 \\
\hline 3- C. A. $75 \mathrm{ppm}+$ sucrose $3 \%+\mathrm{CoSO}_{4} 50 \mathrm{ppm}$ & 34.9 & 27.9 & 14.5 \\
\hline 4- C. A. $75 \mathrm{ppm}+$ sucrose $3 \%+\mathrm{NaOCl} 50 \mathrm{ppm}$ & 46.2 & 33.2 & 18.6 \\
\hline 5- Distilled water (control) & 18.5 & 8.9 & 6.2 \\
\hline
\end{tabular}

\section{REFERENCES}

A.O.A.C. 2005. Association of official analytical chemists. Offic. Meth. Analy. Assoc. Offic. Agric. Chem. $18^{\text {th }}$ ed. Mayland.

Belle, R.A., Mainardi, J.C.C.T., Mello, J.B. and Zachet, D. 2004. Floral opening of Dendranthema grandiflora Tzvelev. "Bronze Repin" after cold storage followed by pulsing. Cienc. Rural., 34(1), 63 - 70.
Carlson, A.S. and Dole, J.M. 2013. Postharvest water quality affects vase life of cut Dendranthema, Dianthus, Helianthus and Zinnia. Sci. Hort., 164, 277 - 286.

Devecchi, M., Trotta, F., Seglie, L., Kim, Y.J., Lava, C., Dolci, M. and Scariot, V. 2009. Effects of anti-ethylene compounds included in nanosponges in improving the postharvest longevity of caration (Dianthus caryophyllus) and buttercup (Ranunculus asiaticus) cut flowers. 
ISHS Acta Hort.: IX Inter. Symp. Post. Qual. Orna. Plants, 30, p. 847.

Doi, M. and Reid, S.M. 1995. Sucrose improves the postharvest life of cut flowers of a hybrid Limonium. Post. Biol. Tech., Hort. Sci., 30(5), 1058 - 1060.

Dubois, M., Gilles, K.A., Hamilton, J.K., Rebers, P. and Smith, F. 1956. Colorimetric method for determination of sugars and related substances. Analy. Chem., 28(3), 350 - 356.

Elanchezhian, R. and Srivastava, G.C. 2001. Effect of growth regulators on senescence of chrysanthemum flowers. Indian J. Plant Phys., 6(3), 233 - 243.

Gupta, V.N., Chakrabarty, D. and Datta, S.K. 2006. Influence of different holding solutions on postharvest behaviour of cut flowers: chrysanthemum (Dendranthema grandiflora Tzvelve.). J. Orna. Hort., 9(2), $80-84$.

Ichimura, K., Kojima, K. and Goto, R. 1999. Effects of temperature, 8-hydroxyquinoline sulphate and sucrose on the vase life of cut rose flowers. Post. Biol. Tech., 15(1), 33-40.

Macnish, A.J., Jiang, C.Z. and Reid, S.M. 2010. Treatment with thidiazuron improves opening and vase life of Iris flowers. Post. Biol. Tech., 56(1), $77-84$.

Macnish, A.J., Leonard, R.T. and Nell, T.A. 2008. Treatment with chlorine dioxide extends the vase life of selected cut flowers. Post. Biol. Tech., 50(2/3), $197-207$.

Meeteren, U., Gelder, H. and leperen, W. 2000. Reconsideration of the use of deionized water as vase water in postharvest experiments on cut flowers. Post. Biol. Tech., 18(2), 169 181.

Mutui, T.M., Emongor, V.E. and Hutchinson, M.J. 2001. Effect of accel on the vase life and post harvest quality of alstroemeria (Alstroemeria aurantiaca) cut flowers. Afr. J. Sci. Tech., Sci. Eng. Series, 2(1), $82-88$.

Nabigol, A., Naderi, R.A., Babalar, M. and Kafi, M. 2006. The effects of some chemical treatments and cold storage on longevity of cut chrysanthemum. Iran. J. Agric. Sci., 37(5), $801-809$.
Pandya, H.A. and Saxena, O.P. 2003. Effects of postharvest light intensity and temperature on the carbohydrate levels and vase life of cut flowers. Acta Hort., 624, 427 - 432.

Rabiza-Swider, J., Skutnik, E. and Chodorska, M. 2012. The effect of growth regulators and preservative on senescence of cut oriental lily 'Helvetia'. Acta Sci. Polo. - Hort. Cult., 11(5), 183 - 194.

SAS Institute Inc. 1996. SAS / STAT Software: Changes and Enhancements through Release 6.12, Cary, NC, SAS Institute Inc.

Shimizu-Yumoto, H. and Ichimura, K. 2013. Postharvest characteristics of cut Dahlia flowers with a focus on ethylene and effectiveness of 6-benzylaminopurine treatments in extending vase life. Post. Biol. Tech., 86, 479 - 486.

Snedecor, G.W. and Cochran, W.G. 1989. Statistical methods. Eighth Edi., lowa State Univ. Press Ames lowa.

Talukdar, M.C., Sarma, B.J., Das, S. and Mahanta, S. 2004a. Effect of pulsing on postharvest quality of chrysanthemum (Dendranthema grandiflora Tzvelve) under different storage conditions. J. Orna. Hort. (New Series), 7(2), $133-140$.

Talukdar, M.C., Das, S. and Sarma, B. 2004b. Effect of holding solution on vase life and conductivity of some standard chrysanthemum (Dendranthema grandiflora Tzvelev) cultivars. Symp. "Biochem. Appro. Util. Explo. Commer. Impor. Plants", Jorhat, India, 12-14, 108 - 112.

Witte, Y., Doorn, G., Wouter, W.G. and Harkema, H. 2014. Effect of antimicrobial compounds on cut Gerbera flowers: Poor relation between stem bending and numbers of bacteria in the vase water. Post. Biol. Tech., 91, $78-83$.

Wood, C.W., Reeves, D.W. and Himelrick, D.G. 1992. Relationships between chlorophyll meter readings and leaf chlorophyll concentration. $\mathrm{N}$ status and crop yield. A Rev.: Proc. Agro. Sco. N.Z., 23, 1 - 9. 